Article

\title{
Analysis of the Methodologic Assumptions of the NOM-020-ENER-2011-Mexican Residential Building Standard
}

\author{
Ignacio R. Martin-Dominguez ${ }^{1}$, , Norma A. Rodriguez-Muñoz ${ }^{2, * \mathbb{D}}$, Claudia K. Romero-Perez ${ }^{1}$, \\ Mario Najera-Trejo ${ }^{1}(1)$ and Naghelli Ortega-Avila ${ }^{2}$ \\ 1 Departamento de Ingenieria Sustentable, Centro de Investigacion en Materiales Avanzados, \\ Calle CIMAV 110, Ejido Arroyo Seco, Durango 34147, Mexico; ignacio.martin@cimav.edu.mx (I.R.M.-D.); \\ claudia.romero@cimav.edu.mx (C.K.R.-P.); mario.najera@cimav.edu.mx (M.N.-T.) \\ 2 Catedras CONACYT, Centro de Investigacion en Materiales Avanzados, Mexico, Calle CIMAV 110, \\ Ejido Arroyo Seco, Durango 34147, Mexico; naghelli.ortega@cimav.edu.mx \\ * Correspondence: norma.rodriguez@cimav.edu.mx; Tel.: +52-614-439-4898
}

Received: 20 August 2018; Accepted: 30 October 2018; Published: 1 November 2018

\begin{abstract}
In Mexico, residents of low income housing mainly achieve thermal comfort through mechanical ventilation and electrical air conditioning systems. Though government and private efforts have risen to meet an increasing demand for social housing, the average construction quality and thermal comfort of new housing stock has decreased over the years. Various programs and regulations have been implemented to address these concerns, including the 2011 residential building standard NOM-020-ENER-2011. This standard attempts to limit heat gains in residential buildings, in order to reduce the energy consumption required from cooling systems, and was intended to be applied throughout Mexico. NOM-020-ENER-2011, however, divides the country into just four climatic zones and only considers the energy use of cooling systems, disregarding heating costs. The recommendations of this policy are thus inadequate for the many regions in Mexico that have mild to moderate winters. This study discusses the assumptions and calculations that underlie NOM-020-ENER-2011, identifying several problems and recommending specific changes to the standard that would lead to greater comfort and lower energy use throughout Mexico.
\end{abstract}

Keywords: building code; housing; energy efficiency; energy policy; cooling

\section{Introduction}

\subsection{Building Standards}

Well-applied energy efficiency standards are among the most cost-effective measures to reduce national greenhouse gas (GHG) emissions. Recent improvements in the design and implementation of building and energy codes have led to important reductions in energy use, contributing to progress towards national climate goals [1]. Indeed, all levels of government in the United States have now recognized how energy efficiency policies reduce GHG emissions [2]. Building standards diverge in their evaluation criteria, according to the nation's specific needs and economic situation. These standards provide solutions and guidelines to reduce energy consumption without compromising quality of life. Some important voluntary standards include the Passivhaus Standard [3] and the Leadership in Energy and Environmental Design (LEED) certification [4].

In many countries, both mandatory and voluntary building standards are based on published mathematical methods. One example is the ISO 13790:2008 method by the International Organization for Standardization (now superseded by ISO 52016-1:2017), which specifies the calculations needed to 
estimate the steady-state energy requirements of both residential and non-residential buildings [5]. This simple method is more convenient than dynamic simulation tools, and has been incorporated into the building standards of the United Kingdom, Greece, Finland, Poland, Norway, and several non-European countries [6,7]. Two other methods that have been used as the basis for policies in several countries include the Total Equivalent Temperature Differential (TETD) method and the Cooling Load Temperature Differential (CLTD) method, both created by the American Society of Heating, Refrigeration and Air-Conditioning Engineers (ASHRAE) [8].

In the United States, the International Energy Conservation Code (IECC) and other state and local codes for energy efficiency in buildings were implemented by the International Conservation Council (ICC) and the ASHRAE, with a special focus on reducing the energy use in the built environment [9]. In Australia, the Nationwide House Energy Scheme (NatHERS) regulates energy efficiency in residential buildings using a 10-star rating scale [9]. In Brazil, the Brazilian Labeling Program works as a voluntary program [10]. This evaluation is based on prescriptive and performance methodologies, which cover lighting, electricity, HVAC (Heating, Ventilation and Air Conditioning), and water heating for new and existing buildings. In the emirate of Dubai (United Arab Emirates), Decree 66 was announced in 2003 to regulate glazing and thermal insulation [11]. Additionally, the Green Building Regulation was announced in 2011 as mandatory for government buildings, and in 2014 for all new buildings.

Evans et al. [12] recently measured the state of implementation of building energy codes in six cities: Rajkot, India; Bogota, Colombia; Tshwane, South Africa; Da Nang, Vietnam; Eskisehir, Turkey; and Mexico City, Mexico. This cities were selected for their strong commitment in the buildings section of the Sustainable Energy for All (SEforALL) nonprofit organization [13]. This study concluded that more robust coordination is needed to provide cities with proper training and funding for compliance, and to ensure that the building standard reflects local priorities. Mexico has a national building energy code, but the lack of coordination between the national and local government is one of the weaknesses on the building's energy efficiency chain. In addition, local authorities do not have the knowledge or proper technical skills to fully understand the energy deficiencies of buildings and proper funding is needed for the implementation of the existing normativity. Also, a fraction of the funding is needed for software and technical training to be applied to support the evaluation and compliance of the local codes on the local level.

In this work, the Mexican International Energy Conservation Code (IECC-Mexico) is also mentioned, but this includes references to the building's energy efficiency standards. Nevertheless, it is also mentioned that the energy efficiency code is not mandatory in Mexico City. Compliance with the code is up to the local government, as is the case in the remaining 2457 municipalities in Mexico [14]. Alfano et al. broadly discuss the concept of Indoor Environmental Quality (IEQ), stating that to apply and trust energy and building codes uncritically will lead to inaccuracies in compliance [15]. This means that to find the optimal design for each case, there is a need to analyze each project under their particular circumstances. The utilization of the building energy codes requires a clear understanding of the underlying concepts; Evans et al. [12] note that this is why the codes are frequently misinterpreted. The authors further emphasize that this happens not only in European countries, but also in Mexico and Brazil.

\subsection{Energy Use}

Economic growth, an increase of population, and urbanization strongly influence the use of energy in the world. The continuous technological developments bring with them a demand for more comfortable conditions in buildings, leading to an increase in the energy demand. In nations where a rapid economic growth is experienced, a larger proportion of the population will demand higher quality dwellings and, consequently, will require more energy for their construction and operation. Furthermore, the increase of home appliance usage in houses also leads to higher energy demands. 
For developing countries like Mexico, electrical subsidies create an important economic burden on the National finances, as well as a peak in the electricity demand [16].

According to the 2016 international energy perspective report by the International Energy Agency (IEA), a great fraction of upcoming increases in energy demand will occur in developing countries, where the economic growth and population expansion will lead to an increase in energy consumption. In developing countries, the projected rise of energy consumption, for the years 2012 to 2040, is estimated at up to 71\%. Five countries-China, United States, India, Russia, and Japan-consumed $51.4 \%$ of the world's energy and produced $47.3 \%$ of the world's GDP during 2014. Mexico occupied 15th place, with $1.3 \%$ of the total energy consumption. On the other hand, the industrial sector consumed $29.2 \%$ of the energy, followed by other key sectors, such as transport $(27.9 \%)$ and residential $(22.7 \%)$. Furthermore, it is expected that energy consumption in buildings will rise $1.5 \%$ annually from 2012 to 2040 [17].

\subsection{Residential Building Programs in Mexico}

According to the 2011 census by INEGI (the Mexican Institute for Statistics and Geography), Mexico contains 112 million inhabitants in 28 million homes, with a mean of 3.9 persons per household. It is expected that by 2050, the number of inhabitants will increase to 122 million [18]. The national energy balance of 2016 states that houses in Mexico are responsible for $14.3 \%$ of the total energy consumption, which represents $4.0 \%$ of the national GHG emissions [17]. The energy use in a single house mainly consists of air conditioning systems, which accounts for up to $44 \%$; meanwhile, lighting and household appliances account for 33\% of the energy total [19].

In Mexico, with the emergence of government housing institutions during the 40's and 50's, improvement strategies were implemented to fight housing shortages. These strategies mainly consisted of new housing production and financing mechanisms. Nowadays, housing programs are constantly being modified to meet the growing demand for housing, and to encourage the incorporation of sustainable elements. The implementation of sustainable housing programs has also stimulated innovation through research [20]. Nonetheless, there are still cities in Mexico where houses are designed and built with minimum consideration of the existing climate. As a result, dwellings must use heating and/or cooling systems exhaustively for many hours throughout the year to achieve minimum levels of thermal comfort.

INFONAVIT (Instituto del Fondo Nacional de la Vivienda para los Trabajadores), the Mexican federal institute for worker's housing, has about 17 million active affiliates and grants more than $70 \%$ of the mortgages in the country [21]. The institute's mission is to provide enough mortgages for its affiliates while maintaining affordable interest rates and quality housing. In Mexico, there are also federal subsidy programs for families earning less than four minimum wages (approximately 500 US USD per month, as of August 2018). If the family requires a subsidy to buy a house and the affiliate is applying for an INFONAVIT mortgage, the institute has a program to promote the construction of sustainable houses.

Two other relevant programs, the "Green Mortgage" initiative (Hipoteca Verde) and "Sisevive-Ecocasa", evaluate future water and energy consumption. More than $96 \%$ of INFONAVIT mortgages (2 million, as of 2007) are classified as "Green Mortgage" (Hipoteca Verde) [21]. INFONAVIT promotes the use of eco-technologies, granting an additional amount for the purchase of systems that save water, electricity, and natural gas. The program has had positive environmental impacts and has resulted in monetary savings for many families.

The "Sisevive-Ecocasa" platform allows designers and housing developers to evaluate their designs from an environmental and energy point of view. It evaluates architectural design, construction materials, and energy and water saving technologies. The calculation is based on achieving energy efficiency by ensuring a rational use of water and energy. The platform confers a score to the evaluated house, comparing the projected demand for water and energy against the reference demand for similar houses. The evaluation is performed using two different calculation tools: one for water and another 
for energy. The spreadsheet calculates a global performance index for the environmental and energy impact. The index is a number between 0 and 100 , which is later converted into a " $G$ " to " $A$ " rating system (similar to the Passivhaus standard).

A consortium of academics was recently called to study passive systems applied to dwellings built in different climatic zones in Mexico, under project SENER 118665 of the Mexican Secretary of Energy. The consortium concluded that these passive systems are scarcely used. It was also found that the current regulations have a tendency to underestimate thermal comfort [22-26]. A study carried out by Lucero-Alvarez et al. [27] looked at the electricity consumption of 20 Mexican cities, calculating heating and cooling requirements and showing that the annual energy demand is directly influenced by the weather. This study also highlighted how energy policy must be based on the real cost of electrical production, which, because of government subsidies, can be significantly different from the costs visible to the consumer.

\subsection{NOM-020-ENER-2011}

In 2011, CONUEE (the National Commission for the Efficient Use of Energy) published the Official Mexican Standard NOM-020-ENER-2011, a mandatory federal standard governing walls and roofs of residential buildings [28]. This standard is meant to be included in the municipal codes; nevertheless, few municipalities have explicitly incorporated it into their requirements. Throughout the rest of this manuscript, NOM-020-ENER-2011 will be abbreviated as NOM-020.

The objective of NOM-020 is to limit heat gain in the envelope (walls and roof) of dwellings, with the aim of reducing energy consumption due to air conditioning (cooling) systems. It is mainly targeted at new single-family housing and multi-unit residential buildings. The NOM-020 methodology determines the efficiency of a planned building by calculating heat gain through its envelope, and rating it against a reference building. NOM-020 defines the reference building, as well as the environmental conditions in the city where the building is to be located. To comply with NOM-020, the heat gains of the planned building must be less than those obtained for the reference building.

In 2013, NOM-020 was withdrawn from federal housing subsidies and from the "Green Mortgage" guidelines [29]. New restrictions on the applicability of the standard were published in October 2016, limiting its field of application to new single-family homes and restored residential buildings in cities subject to tariffs $1 \mathrm{C}, 1 \mathrm{D}, 1 \mathrm{E}$, and $1 \mathrm{~F}$ of the federal electrical pricing scheme. These electricity rates apply when the mean summer temperatures range from $30^{\circ} \mathrm{C}$ to $33^{\circ} \mathrm{C}$ [30]. Additionally, a modification was made to the global heat transfer coefficient; the main argument for the adjustment was that the previously established reference value had been proven to be too strict [29].

NOM-020 differs from international standards in a few important respects. The Federal Law on Metrology and Standardization [31] allows federal standards to establish the characteristics and specifications of products; that is, to establish the minimum or maximum quantities to be met by the standards. This is an important legal difference between Mexican and international standards. A smaller but notable issue is that, in NOM-020, the global heat transfer coefficient is designated as " $K$ ", in disagreement with the international convention to use " $U$ ". This usage originates in NOM-008-SCFI-2002 [32], which establishes the units of measurement for federal standards and claims to be in agreement with ISO 31-4 (1978) [33].

NOM-020 also has several conceptual, technical, and methodological flaws. The standard has been discussed by numerous academics, design and construction professionals, and also the CONUEE (National Commission for the Efficient Use of Energy), and found to have a limited ability to reduce the use of cooling systems in warm and hot climates. An additional problem is that most municipal building standards fail to require the application of NOM-020, even though this federal regulation is currently active and mandatory. Since municipalities are the entities that grant building permits, NOM-020 is generally ignored.

There are many additional non-technical issues with Mexican energy building codes, which are not investigated in this work but remain relevant to the public: 
- $\quad$ The standard for energy efficiency in non-residential buildings (NOM-008-ENER-2001 [34], published in 2001) is not being applied, despite also being mandatory.

- In 2011, NOM-020-ENER-2011 [28] was published, and great efforts are being made in regards to the training of technicians for verification. Also, seminars aiming at the incorporation of "NOM-008 and NOM-020" into the local regulations are happening in some municipalities.

- As stated in the objectives of NOM-020, the methodology focuses on calculating total annual heat gains through building envelopes. This leaves cities with a temperate climate completely out of the regulatory scope.

- Mexican standards have apparently been created based almost entirely on old ASHRAE methodologies. Both NOM-020 and NOM-008-ENER-2001 have the same bibliographic references and declare non-conformity with any international existing codes.

The relevance of having a federal standard, such as "NOM-020-ENER-2011", would be notable when applied at least to new constructions. The correct implementation of this standard should also contribute to the reduction in the energy consumption for residential buildings and, therefore, to the consequent decrease in greenhouse gas emissions. It is imperative to highlight the importance of construction quality and energy efficiency attributes of the new residential buildings and houses in Mexico, so that families will always be concerned about the operating costs of the house (energy, water, etc.), in addition to becoming a family asset.

The above mentioned concerns are examples of non-technical issues related to the Mexican standard; however, the purpose of this work is to improve the applicability of the normativity and to ensure that the objective of reducing energy in residential buildings is met. In the following sections, this study analyzes the assumptions and calculations that underlie NOM-020. Recommendations to improve the current methodology are presented and discussed.

\section{Methodological Analysis}

In this section, the methodology in NOM-020 is reverse-engineered and compared against the ASHRAE methodology on which it is based. Section 2.1 introduces the concept of equivalent temperature $\left(t_{e}\right)$ and its limitations. Sections 2.3 and 2.4 describe how $t_{e}$ is incorporated into NOM-020, the assumptions that underlie this usage, and the resulting economic implications for manufacturers of thermal insulation.

\subsection{Heat Flux Calculation for Reference Buildings}

NOM-020 is based on the TETD (Total Equivalent Temperature Differential) method published by the ASHRAE in the 1960s. This method is based on the one-dimensional heat equation for transient states, and solved by Fourier series for composite wall elements. TETD requires numerous tables of values pre-calculated for representative construction elements. This method was tedious to use and limited to the information contained in the available data tables, so ASHRAE eliminated TETD in the 1989 edition of its Fundamentals manual. Though new methods were proposed for the calculation of thermal loads, they did not have good acceptance in practice [35]. In 1991, the ASHRAE Technical Committee decided to update TETD and include it again in the Fundamentals; this time as a computational methodology that would use basic equations and not pre-calculated tabulated values. NOM-020 was based on a pre-1989 version of TETD, and thus requires tables of pre-calculated values.

For calculating the reference heat gain, NOM-020 only considers two types of heat flows that occur inside buildings: conductive heat flow through opaque elements and radiative heat flow through translucent building components. Conductive heat gains are calculated through the conduction heat gain equations (Section 7.1.2 [28]).

Since NOM-020 seeks to limit heat gains in homes, one might expect the standard to establish a single maximum value of heat flow per unit area (heat flux $\mathrm{W} / \mathrm{m}^{2}$ ), and that said limit would be determined for the whole country by technical and economic considerations. NOM-020 does not 
mention heat flux, but instead lists several Mexican cities and for each one, prescribes exact values of the global coefficient of heat transfer $U$ (called " $K$ " in NOM-020), of the internal building temperature $T_{\text {int }}$, and of the external equivalent temperature $\left(t_{e}\right)$. These parameters taken from Table 1 , from the Appendix A of the NOM-020-ENER-2011 document [28], effectively give each city on the list its own individual heat flux requirement, calculated and shown in Figure 1.

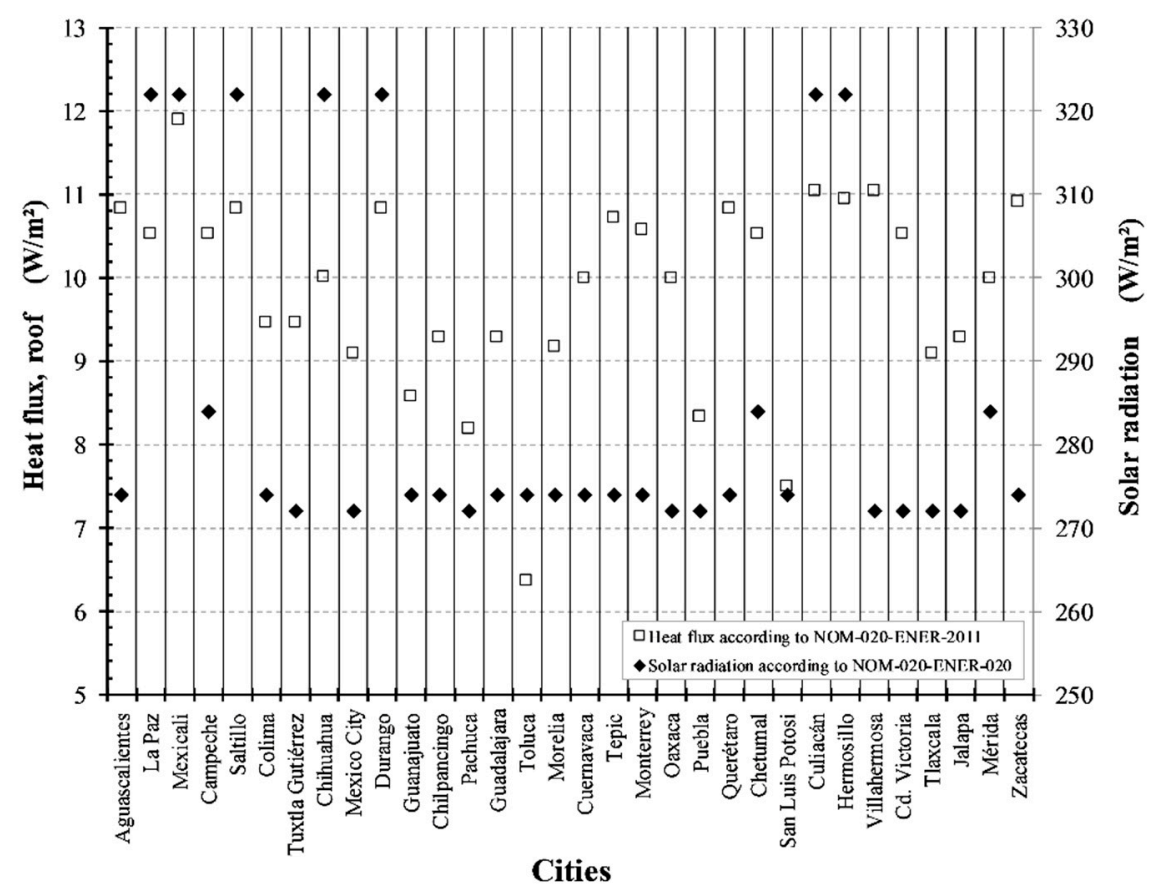

Figure 1. Calculated heat flux and assigned solar radiation for Mexican capital cities.

Figure 1 shows the heat flux values effectively required by NOM-020 for Mexican capitals, along with the mean annual solar radiation that the standard lists for those cities (Table 1 [28]). The calculated maximum permitted heat flux ranges from 6.36 to $11.9 \mathrm{~W} / \mathrm{m}^{2}$ among the capital cities mentioned in NOM-020. The standard fails to explain the justification for these different maximum values for each city. Furthermore, it is observed that NOM-020 assigns these cities one of only four different radiation levels, which is clearly a simplification, but is also not explained.

\subsection{Equivalent Temperature Calculation $\left(t_{e}\right)$}

The equivalent temperature $\left(t_{e}\right)$, also named the Sol-Air temperature, in the ASHRAE Fundamentals Manual [36], is an artificial temperature used to simplify the calculation of heat flux. It uses the instantaneous heat flux equation, and includes the effects of convection, solar radiation, and infrared emission. The equivalent temperature $\left(t_{e}\right)$ is the outdoor air temperature that gives the same rate of heat entry into the surface as the combination of incident solar radiation, radiant energy exchange with the sky and the outdoor surroundings, and convective heat exchange with outdoor air [36]. Equation (1) defines heat flux for an outdoor surface exposed to the sun. Equation (2) shows how heat flux can also be calculated from the equivalent temperature $\left(t_{e}\right)$ and the outdoor surface temperature $\left(t_{s}\right)$ of the envelope. The equivalent temperature $\left(t_{e}\right)$ in Equation (3) follows from Equations (1) and (2).

$$
\begin{gathered}
\frac{q}{A}=\alpha E_{t}+h_{o}\left(t_{o}-t_{s}\right)-\varepsilon \Delta R \\
\frac{q}{A}=h_{o}\left(t_{e}-t_{s}\right) \\
t_{e}=t_{o}+\frac{\alpha E_{t}}{h_{o}}-\frac{\varepsilon \Delta R}{h_{o}}
\end{gathered}
$$


where $q$ is the heat flux, $A$ refers to the surface area, $\alpha$ is the surface's solar absorptivity; $E_{t}$ is the total solar radiation incident on the surface $\left(\mathrm{W} / \mathrm{m}^{2}\right) ; h_{0}$ is the heat transfer coefficient from long-wave radiation and convection at the outer surface $\left(\mathrm{W} / \mathrm{m}^{2} \cdot \mathrm{K}\right) ; t_{o}$ and $t_{s}$ are the outdoor air and wall surface temperatures, respectively; and $\varepsilon$ is the infrared emissivity of the surface. $\Delta R$ is the difference between the long wave radiation incident on the surface from the sky and surroundings, and the radiation emitted by a black body at ambient air temperature $\left(\mathrm{W} / \mathrm{m}^{2}\right)$.

NOM-020 expands the concept of equivalent temperature $\left(t_{e}\right)$ to include the thermal resistance and convective heat flux coefficient from inside the building. This allows the use of the interior temperature, as shown in Sections 7.1.1.1 and 7.1.2.1 of the AHSRAE procedure (American Society of Heating, Refrigeration and Air-Conditioning Engineers) [36]. Also included in the procedure is the calculation of the sky temperature, which requires detailed information such as: ambient temperature, solar radiation, and absorptivity of the surface exposed to the sun. Instant sky temperature values throughout the day can be calculated to produce a representative value for Equation (2).

\subsection{Equivalent Temperature in NOM-020-ENER-2011}

In NOM-020, it is not clear how the equivalent temperature $\left(t_{e}\right)$ is calculated for each city. Table 1 shows the assigned values of $K$ (for each building envelope element), $t_{i n t}$ and $t_{e}$, from which the allowed maximum heat flux can be calculated for cities of all the states of Mexico. Neither NOM-008 nor NOM-020 mention that they were developed following Huang's methodology. Nevertheless, Huang et al. [37] published a paper explaining the methodology used in NOM-008. NOM-020 follows the exact same methodology.

Huang et al. [37] used the DOE-2 software (Department of Energy's (DOE) Building Technologies Office, Washington, DC, USA) to calculate the cooling required for the months of April through October. The values for Solar Heat Gain, meanwhile, were taken from four cities in Mexico (Mexico City, Monterrey, Mexicali, and Mérida) and merely assigned to the others. According to Huang et al. [37], this simplification was applied due to the absence of historical radiation information for all of the cities in Mexico. With the Solar Heat Gain values of the cities mentioned above, the equivalent temperatures for each component were calculated by dividing the Solar Heat Gain between the thermal conductivity, the area, and the hours of operation of the cooling equipment:

$$
T_{e q}=T_{i n}+\frac{Q_{c}}{K \cdot A \cdot t}
$$

In Equation (4), $T_{e q}$, is the equivalent temperature $\left(t_{e}\right)$ in ${ }^{\circ} \mathrm{C} ; T_{\text {in }}$ is the set temperature of the cooling system, which for this case is considered $25^{\circ} \mathrm{C} ; Q_{c}$, is the total cooling load, which was calculated with DOE-2; $K$ is the thermal conductance (global heat transfer coefficient, $U$ ) of the constructive system $\left(\mathrm{W} / \mathrm{m}^{2} \mathrm{~K}\right) ; A$ is the superficial area of the component in $\left(\mathrm{m}^{2}\right)$; and $t$ is the cooling system working time (h). In the work by Huang et al. [37], they derived the $t_{\mathrm{e}}$ values of four selected Mexican cities, from DOE-2 simulations. They compared the results to several monthly weather temperature statistics, and found that the best correlation occurred with average monthly dry-bulb temperatures. Then, they applied the regression equations to weather data from the Mexican National Meteorological Service to produce the equivalent temperatures of the 65 major cities reported in the NOM-008 standard.

\subsection{Equivalent Temperature ( $\left.t_{e}\right)$ : Theoretical vs NOM-020-ENER-2011}

Equivalent (Sol-Air) temperatures and cooling loads can be calculated from the emissivity and absorptivity of a surface. In the current construction market, one can find a wide variety of coatings with various values of solar absorptivity $(\alpha)$. As a consequence, each material will have different cooling loads, which means that the equivalent temperatures $\left(t_{e}\right)$ are different. Table 1 from NOM-020 (entitled "Values to calculate heat flow through the envelope") contains $t_{e}$ values for roofs, walls, and windows, at different orientations ( $\mathrm{N}, \mathrm{E}, \mathrm{S}$, and $\mathrm{W})$ in all considered cities. Nevertheless, NOM-020 assumes a single solar absorptivity value for all surfaces. 
In this work, the equivalent temperature $\left(t_{e}\right)$ was calculated for various values of solar absorptivity, $\alpha$, using the equation suggested by ASHRAE. Table 1 and Figure 2 show average monthly dry bulb temperatures $\left(t_{0}\right)$ and solar radiation $\left(E_{t}\right)$, respectively, for the cities considered in the standard (data from SMN (Servicio Meteorologico Nacional-Mexican National Meteorological Service)). The value of $13 \mathrm{~W} / \mathrm{m}^{2} \mathrm{~K}$ was taken from NOM-020 for the convective heat transfer coefficient $\left(h_{0}\right)$. A value of $4{ }^{\circ} \mathrm{C}$ was used to determine the infrared cooling effect due to the emissivity of horizontal surfaces [36]. Equivalent temperatures $\left(t_{e}\right)$ were calculated using different values of absorptivity, and the values were then compared with the values from NOM-020.

Figure 2 shows that there is no correlation between the temperatures from Table 1 and the solar radiation values contained in NOM-020; the standard assumes that in Mexico, there are only four different levels of solar radiation. Because of this inaccurate input to heat transfer calculations, NOM-020 produces inadequate recommendations for many of the country's climates.

Figures 3 and 4 depict equivalent temperatures (both calculated and from NOM-020) for the absorptivity values of 0.6 and 0.9 , respectively. It is apparent that the NOM- 020 values best match the calculated values when $\alpha=0.9$. This value of $\alpha$ is stipulated by ASHRAE for dark surfaces. Thus, NOM-020 uses an inflated value of solar absorptivity for the calculation of reference heat fluxes, implicitly assuming that all building surfaces are dark $(\alpha=0.9)$.

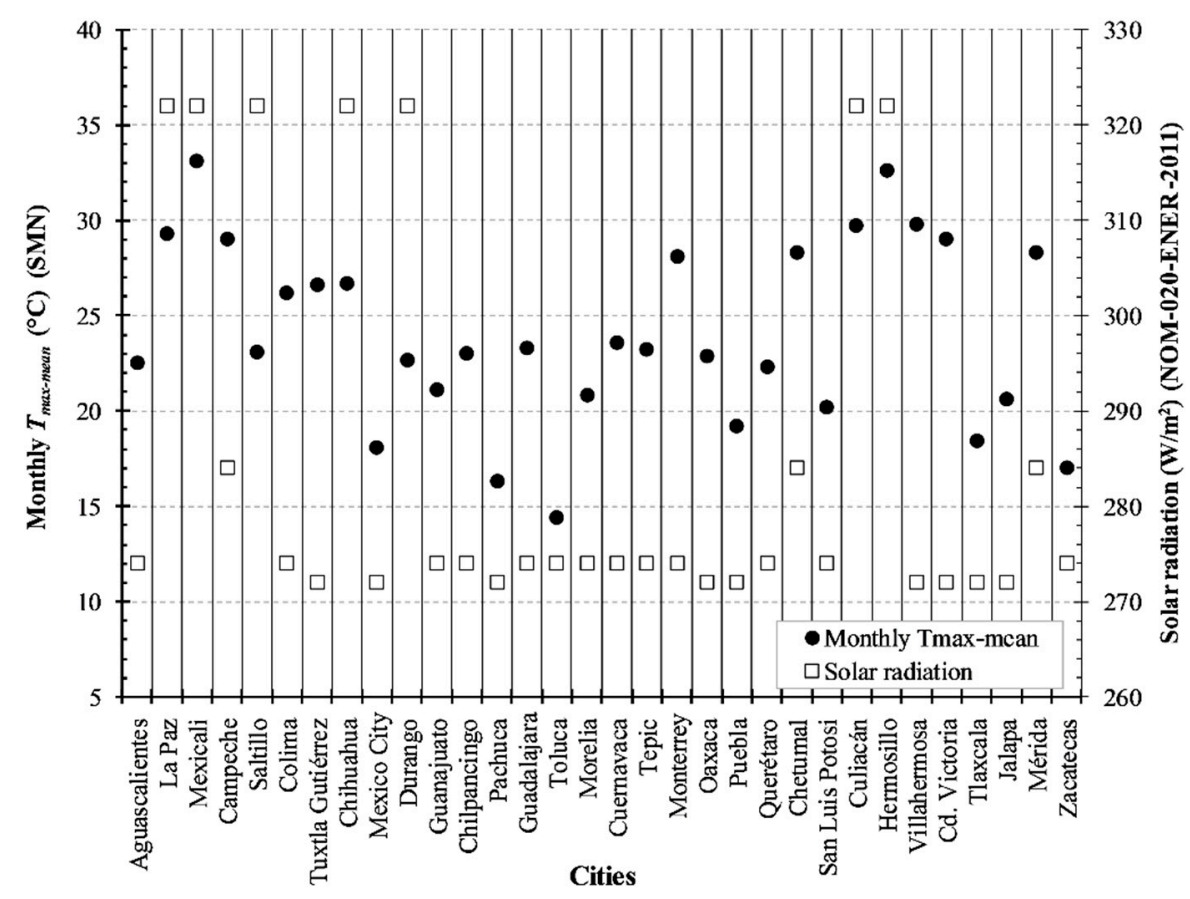

Figure 2. Mean monthly maximum temperature and solar radiation in capital cities in Mexico. SMN: Servicio Meteorologico Nacional (Mexican National Meteorological Service). 
Table 1. Monthly mean temperatures for state capital cities in Mexico ( $\left.{ }^{\circ} \mathrm{C}\right)$. SMN 1951-1980 [38].

\begin{tabular}{|c|c|c|c|c|c|c|c|c|c|c|c|c|c|c|}
\hline City & January & February & March & April & May & June & July & August & September & October & November & December & Annual & $T_{\max }$ \\
\hline Aguascalientes, Ags. & 13.7 & 14.9 & 17.9 & 20.5 & 22.5 & 21.9 & 20.5 & 20.3 & 19.7 & 17.9 & 15.7 & 13.8 & 18.3 & 22.5 \\
\hline Mexicali, B.C. & 12.3 & 14.8 & 17.1 & 20.7 & 24.6 & 29.5 & 33.1 & 32.5 & 29.7 & 23.8 & 17.1 & 12.8 & 22.3 & 33.1 \\
\hline La Paz, B.C.S. & 17.9 & 18.6 & 19.6 & 21.8 & 23.8 & 26.2 & 28.9 & 29.3 & 28.7 & 26.3 & 22.5 & 19.2 & 23.6 & 29.3 \\
\hline Campeche, Camp. & 23.3 & 24 & 26.3 & 28 & 29 & 28.6 & 27.9 & 27.8 & 27.6 & 26.6 & 24.8 & 23.4 & 26.4 & 29 \\
\hline Saltillo, Coah. & 12.3 & 13.2 & 17.8 & 20.3 & 22.5 & 23.1 & 22.9 & 22.3 & 20.5 & 18.2 & 15.1 & 13.1 & 18.4 & 23.1 \\
\hline Colima, Col. & 22.6 & 22.8 & 23.6 & 24.8 & 26.1 & 26.2 & 25.4 & 25.2 & 24.8 & 24.8 & 24.3 & 23.1 & 24.5 & 26.2 \\
\hline Tuxtla Gutiérrez, Chis. & 22.7 & 23.1 & 24.9 & 26.2 & 26.6 & 25.7 & 25.2 & 25 & 24.9 & 24.3 & 23.2 & 22.7 & 24.5 & 26.6 \\
\hline Chihuahua, Chih. & 9.8 & 11.9 & 15.4 & 19.7 & 23.6 & 26.7 & 25.3 & 24.2 & 22.3 & 18.6 & 13.4 & 10 & 18.4 & 26.7 \\
\hline Mexico City & 12.9 & 14.5 & 17 & 18 & 18.1 & 17.2 & 16 & 16.3 & 15.7 & 15.1 & 14 & 12.9 & 15.6 & 18.1 \\
\hline Durango, Dgo. & 11.9 & 13.5 & 16.8 & 19.3 & 21.7 & 22.7 & 21 & 20.4 & 19.6 & 18.8 & 15.5 & 12.8 & 17.8 & 22.7 \\
\hline Guanajuato, Gto. & 14.3 & 15.6 & 18.2 & 20.2 & 21.1 & 20.2 & 19.1 & 19 & 18.4 & 17.6 & 16 & 14.6 & 17.9 & 21.1 \\
\hline Chilpancingo, Gro. & 19.4 & 20.2 & 21.6 & 22.8 & 23 & 22.1 & 21.3 & 21.4 & 21 & 21.3 & 20.5 & 19.6 & 21.2 & 23 \\
\hline Pachuca, Hgo. & 12.1 & 13 & 15.4 & 16.3 & 16.3 & 15.4 & 14.5 & 14.7 & 14.2 & 13.5 & 12.8 & 12.1 & 14.2 & 16.3 \\
\hline Guadalajara, Jal. & 15.6 & 17 & 19.4 & 21.8 & 23.3 & 22.6 & 20.6 & 20.6 & 20.3 & 19.1 & 17.2 & 15.7 & 19.4 & 23.3 \\
\hline Toluca, Méx. & 9.4 & 10.5 & 12.7 & 14.1 & 14.4 & 14 & 13 & 13.1 & 13 & 12.1 & 10.9 & 9.6 & 12.2 & 14.4 \\
\hline Morelia, Mich. & 14.6 & 15.8 & 18.3 & 20 & 20.8 & 20 & 18.5 & 18.5 & 18.3 & 17.4 & 16.1 & 14.7 & 17.8 & 20.8 \\
\hline Cuernavaca, Mor. & 19.1 & 20.2 & 22.3 & 23.6 & 23.6 & 22.1 & 21.1 & 21 & 20.5 & 20.3 & 20 & 19.3 & 21.1 & 23.6 \\
\hline Tepic, Nay. & 17 & 17.2 & 18.3 & 20 & 21.7 & 23.1 & 23.2 & 23.2 & 23.1 & 22.4 & 19.8 & 18 & 20.6 & 23.2 \\
\hline Monterrey, N.L. & 14.9 & 16.7 & 20.3 & 23.9 & 25.9 & 27.5 & 28.1 & 27.8 & 25.7 & 22.2 & 17.8 & 15.3 & 22.2 & 28.1 \\
\hline Oaxaca, Oax. & 17.8 & 19.1 & 21.4 & 22.8 & 22.9 & 21.4 & 20.6 & 20.7 & 20.3 & 19.6 & 18.6 & 17.7 & 20.2 & 22.9 \\
\hline Puebla, Pue. & 13.8 & 15 & 17.6 & 18.7 & 19.2 & 18.1 & 17.1 & 17.5 & 17 & 16.5 & 15.2 & 13.8 & 16.6 & 19.2 \\
\hline Querétaro, Qro. & 15.4 & 16.6 & 19.4 & 21.5 & 22.3 & 21.6 & 20.3 & 20.3 & 19.7 & 18.2 & 17.1 & 15.5 & 19 & 22.3 \\
\hline Chetumal, Q. Roo. & 24.3 & 24.5 & 26.6 & 27.2 & 28.3 & 27.9 & 27.7 & 27.7 & 27.3 & 26.4 & 25.2 & 23.8 & 26.4 & 28.3 \\
\hline San Luis Potosí, S.L.P. & 12.7 & 13.3 & 17.1 & 18.9 & 20.2 & 19.1 & 18 & 17.5 & 17.5 & 16 & 14.3 & 12.8 & 16.5 & 20.2 \\
\hline Culiacan, Sin. & 19.9 & 20.6 & 21.9 & 24.6 & 27.3 & 29.6 & 29.7 & 29.1 & 29 & 27.7 & 24 & 20.7 & 25.3 & 29.7 \\
\hline Hermosillo, Son. & 16.6 & 18.1 & 20.1 & 23.7 & 27.2 & 31.8 & 32.6 & 31.5 & 31 & 27.2 & 21 & 17 & 24.8 & 32.6 \\
\hline Villahermosa, Tab. & 25.1 & 26.5 & 27.7 & 29.2 & 29.8 & 29.6 & 29.1 & 29.6 & 29.4 & 28.5 & 27.3 & 25.7 & 28.1 & 29.8 \\
\hline Cd Victoria, Tamps. & 16.9 & 18.1 & 21.8 & 25.8 & 27.6 & 28.8 & 28.8 & 29 & 27.2 & 23.9 & 19.8 & 17.3 & 23.8 & 29 \\
\hline Tlaxcala, Tlax. & 13.7 & 14.8 & 17.1 & 18.4 & 18.4 & 17.9 & 16.9 & 17 & 16.9 & 16.3 & 15.1 & 14 & 16.4 & 18.4 \\
\hline Jalapa, Ver. & 14.8 & 15.5 & 18.1 & 20.1 & 20.6 & 19.9 & 19.2 & 19.6 & 19.2 & 17.9 & 16.5 & 15.4 & 18.1 & 20.6 \\
\hline Mérida, Yuc. & 22.9 & 23.5 & 26 & 27.5 & 28.3 & 27.8 & 27.3 & 27.4 & 26.9 & 25.7 & 24.3 & 23.1 & 25.9 & 28.3 \\
\hline Zacatecas, Zac. & 9.9 & 10.7 & 13 & 15.7 & 17 & 16.3 & 14.8 & 14.7 & 14 & 13.1 & 12.2 & 10 & 13.5 & 17 \\
\hline
\end{tabular}

SMN: Servicio Meteorologico Nacional (Mexican National Meteorological Service). 


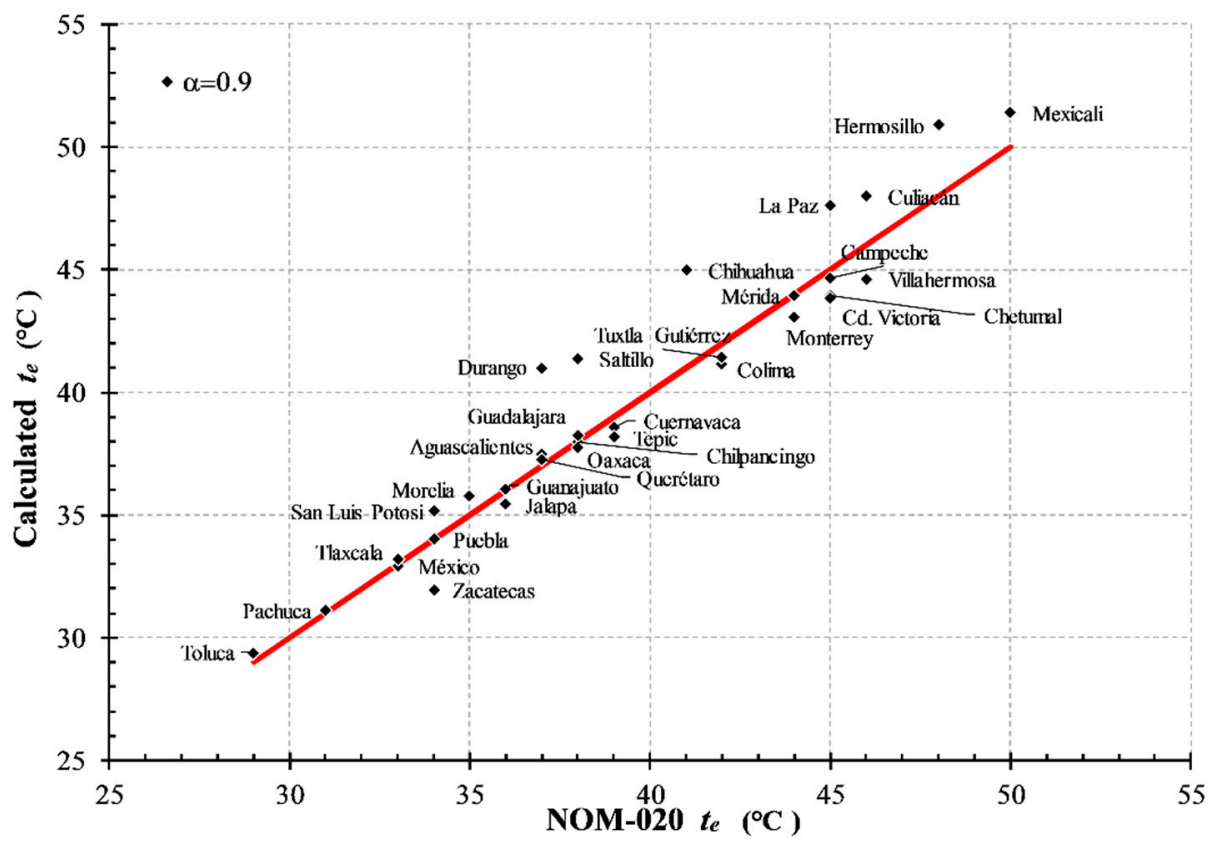

Figure 3. NOM-020-ENER-2011 $\left(t_{e}\right)$ (black squares) vs calculated $\left(t_{e}\right)$ (red line), $\alpha=0.9$.

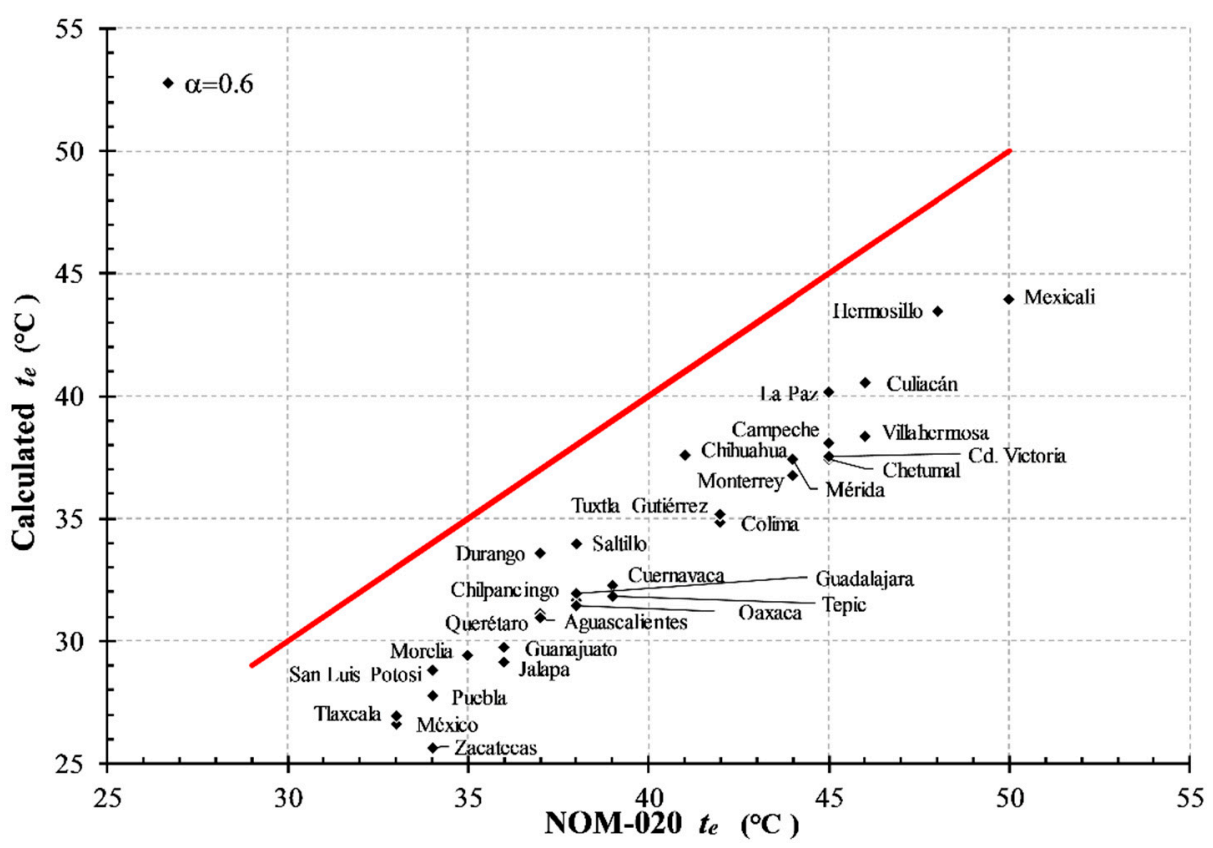

Figure 4. NOM-020-ENER-2011 $\left(t_{e}\right)$ (black squares) vs calculated $\left(t_{e}\right)$ (red line), $\alpha=0.6$.

\section{Results and Discussion}

The methodology of NOM-020 implicitly assumes heat fluxes that correspond to a dark-colored building $(\alpha=0.9)$. This assumption is a useful illustration of the worst-case scenario. When used in the general methodology of the federal building standard, however, this assumption forces constructors and users to use excessive amounts of thermal insulation to comply with the code.

Figure 5 shows a list of traditional building materials with absorptivity $(\alpha)$ values from 0.14 to 0.95 . On the figure are highlighted with a dotted line, from the left to the right, highly reflective materials and coatings, materials and coatings with normal reflectivity and the ASHRAE dark color convention (marked in a red board), respectively. There is a wide variety of commercially available reflective coatings whose absorptivity values are much lower than the values assumed by NOM-020; the code 
will prescribe an excessive amount of insulation for any building that uses those coatings. Building designers and users should have the opportunity to select the most practical and / or economic approach to energy efficiency, and not have to always purchase enough thermal insulation for a building covered in dark paint.

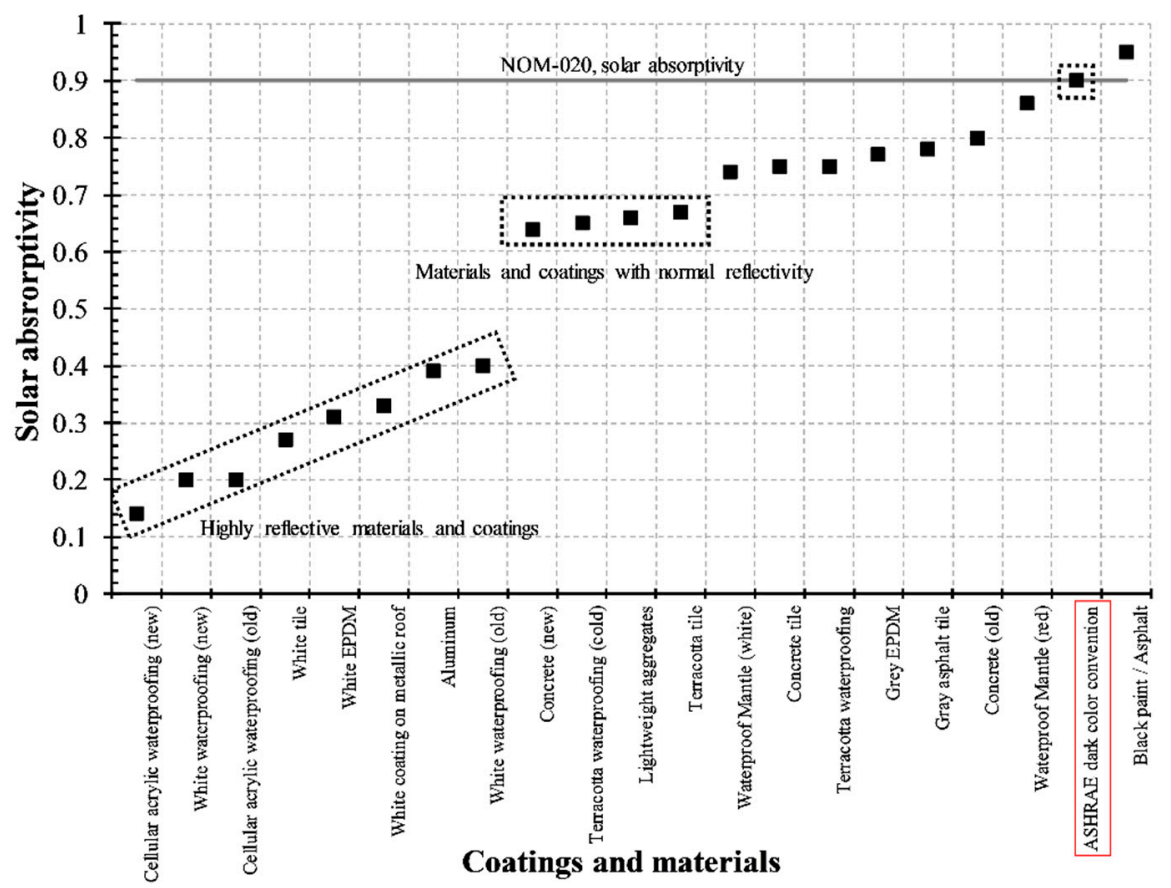

Figure 5. Solar absorptivity of commercial materials and coatings. EPDM: Ethylene Propyelene Diene Methylene.

\subsection{Selection of Mean Temperature}

NOM-020 provides a list of $t_{e}$ values for all state capitals, without providing the parameters from which $t_{e}$ was calculated. In this study, instead of using the $t_{e}$ values provided in the standard, it is recommended that the annual mean maximum temperature value for each city is used. Thus, this study re-calculated $t_{e}$ values from annual mean maximum temperatures $\left(T_{\max }\right)$, as published by the SMN. Table 1 shows the annual and monthly mean temperatures for the state capitals, with $T_{\max }$ in the last column.

\subsection{Solar Absorptivity}

There is a wide diversity of roof coatings which have different values for solar absorptivity. These coatings have values ranging from $\alpha=0.14$ for a new acrylic waterproof coating to $\alpha=0.9$ for a black asphalt coating. In the literature, materials and coatings used for cool roofs have a solar absorptivity of 0.45 and an emissivity of 0.8 . Figure 5 compares the value used in NOM-020 $(\alpha=0.9)$ to the solar absorptivity values for different types of commercial coatings.

\subsection{Calculation of Equivalent Temperature Considering Solar Absorptivity}

By incorporating the different values of absorptivity of the coatings, it is possible to calculate new equivalent temperatures $\left(t_{e}\right)$. For this calculation, it is possible to use the solar radiation data from NOM-020 and the mean maximum temperatures from SMN. Figure 6a shows that the calculated values of $t_{\mathrm{e}}$ (ASHRAE methodology) are low when solar absorptivity is low. In some cases, the interior temperatures $\left(T_{\text {int }}\right)$ are lower than those presented in NOM-020. In addition, because of the high solar reflectivity of aged acrylic cellular coatings, passive cooling results in a $t_{\mathrm{e}}$ lower than the outside ambient temperature. 


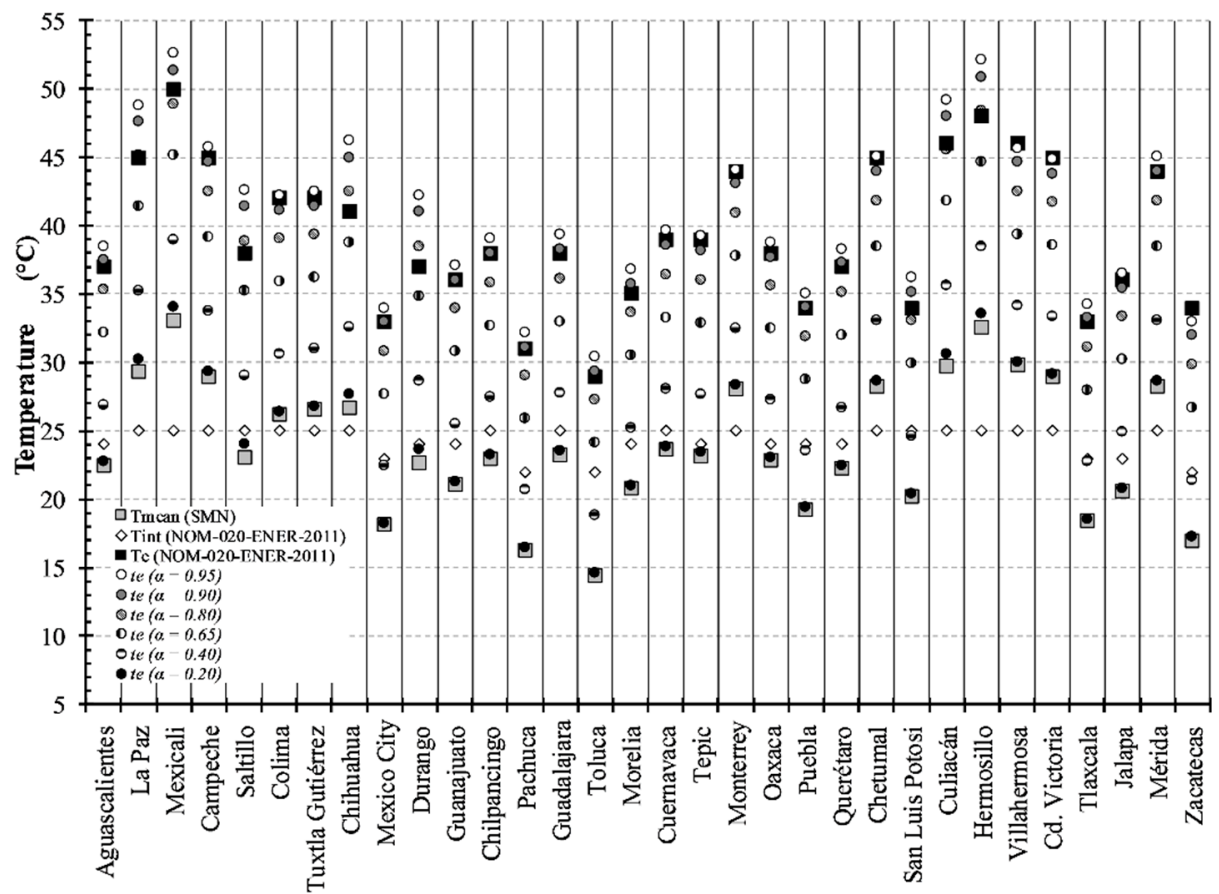

(a)

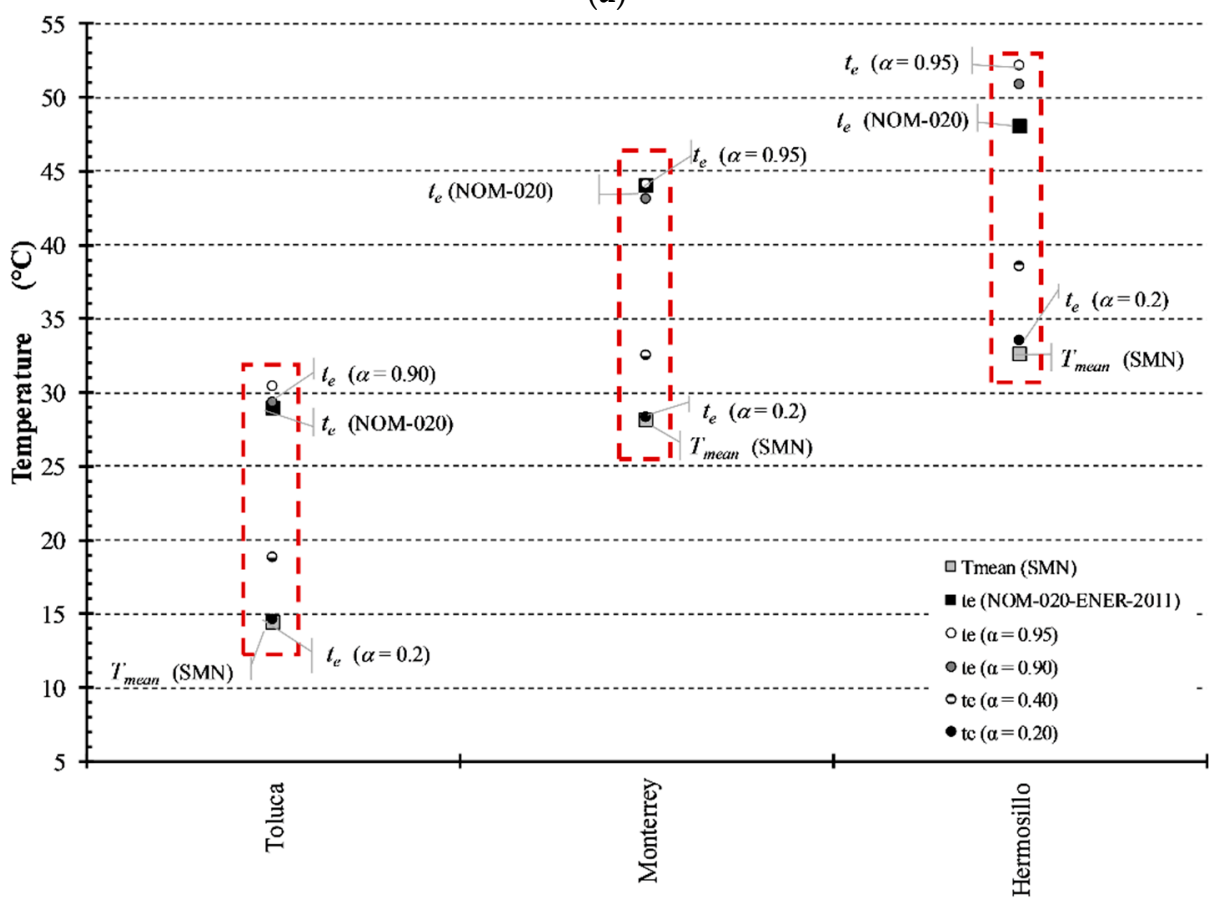

(b)

Figure 6. Equivalent temperature $\left(t_{e}\right)$ at different solar absorptivity values. (a) All cities, several absorptivity values; (b) Selected cities, simplified view.

For a building exposed to sunlight, a high solar absorptivity $(\alpha=0.9-0.95)$ maximizes the effect of solar radiation on the overall heat flow into the building (the first term in Equation (1)) and results in a higher $t_{e}$. Figure $6 \mathrm{~b}$ shows these high predicted $t_{e}$ values for three selected cities. The assumption that buildings are covered in dark paint is important, because solar radiation can affect heat flux as much as the difference between indoor and outdoor temperatures.

Figure 7 shows the temperature gradients $\left(t_{e}-t_{\text {int }}\right)$ that induce heat fluxes across the building envelope. The $t_{e}$ predicted by NOM-020 always predicts large positive gradient values, or large heat 
gains to the building. The gradients obtained considering low solar absorptivity values $(\alpha=0.2$, $\alpha=0.4$ ) are always smaller, and in some cases, became negative. Even in sunny conditions, a negative temperature gradient will induce a heat flux towards the outside of the building, thereby reducing air conditioning operation costs. This effect has been previously measured and reported in the literature [22]. Materials and coatings with low solar absorptivity not only reduce heat gains during summer, but also produce passive cooling during sunny periods. Using NOM-020 to calculate heat fluxes indicates a need for insulation in most Mexican cities. The use of reflective and emissive coatings, on the other hand, could remove the need for such insulation by blocking heat gains and even encouraging passive cooling.

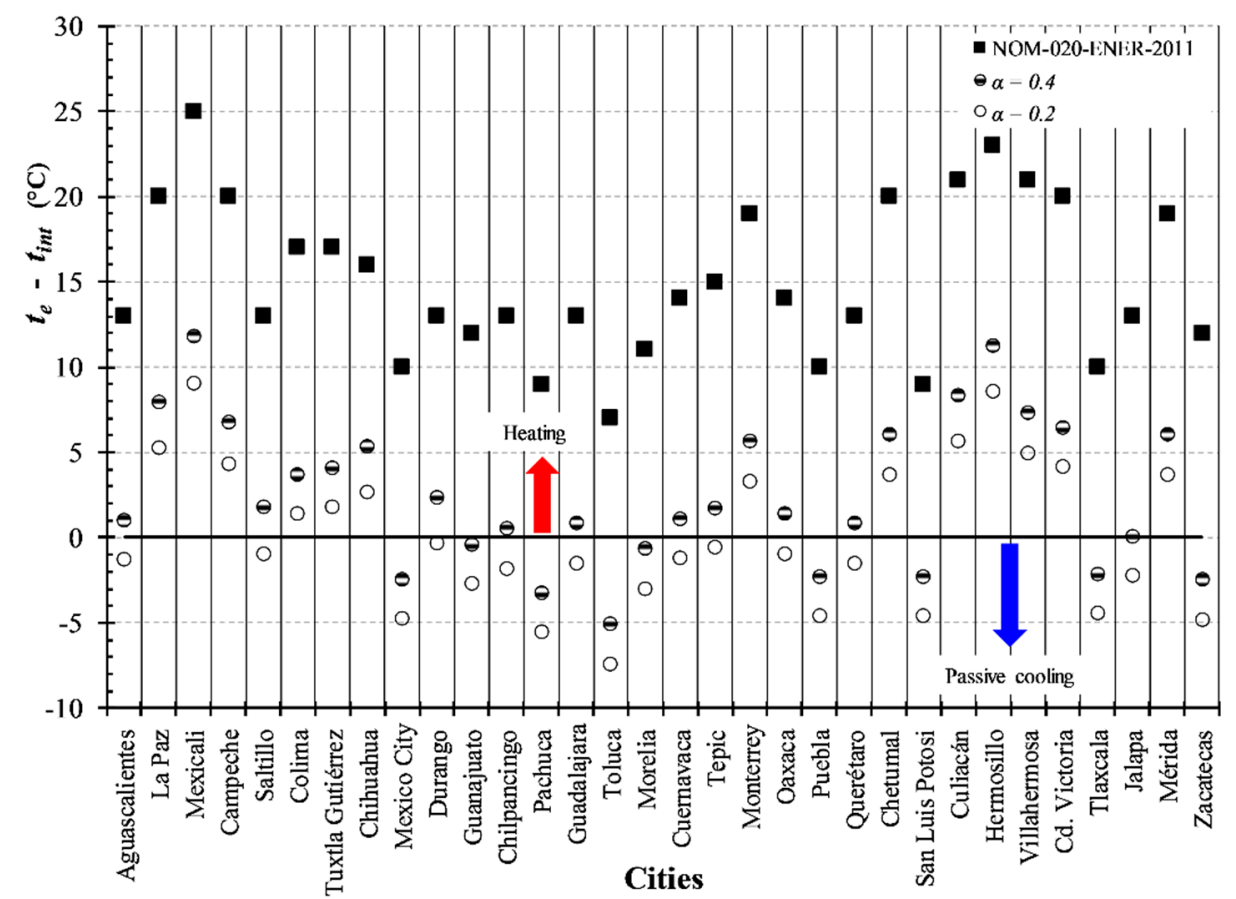

Figure 7. Temperature gradient in roofs at different absorptivity values.

\subsection{NOM-020-ENER-2011 Thermal Resistivity}

One of the objectives of NOM-020 is to ensure that the envelope heat fluxes of different buildings do not exceed the maximum values shown in Table 1 of the NOM-020 [28]. Those maximum values were determined using this equation:

$$
\phi_{r c i}=\sum_{j=1}^{n}\left[K_{j} \cdot A_{i j} \cdot\left(t_{e i}-t\right)\right]
$$

where $\phi_{r c i}$ is the conductive heat gain through the building envelope (W) and $A_{i j}$ refers to each of the envelope's element area $j$, with an $i$ orientation $\left(\mathrm{m}^{2}\right)$. Values for the global heat transfer coefficient $U$ (" $K$ ", in the standard), equivalent temperatures $\left(t_{e}\right)$, and temperatures $(t)$ were obtained from Table 1 of NOM-020 [28]. Using the reference heat fluxes, the building interior temperatures, the calculated equivalent temperatures, and the solar absorptivity, it is possible to recalculate the global heat transfer coefficient $U$ (" $K$ ", in the standard) and the thermal resistance $M\left(\mathrm{~m}^{2} \mathrm{~K} / \mathrm{W}\right)$. The thermal resistance $M$ is mentioned as the global thermal insulation, and it is defined in the Mexican Standard as:

$$
M=\frac{1}{K}
$$




\subsection{Required Thickness of Thermal Insulation}

A case study was carried out to calculate the insulation thickness necessary to reach the values of global heat transfer coefficient $U$ (" $K$ ", in the standard) required by NOM-020 (equivalent to an overall thermal resistance of $0.4083 \mathrm{~m}^{2} \mathrm{~K} / \mathrm{W}$ ). This case study considered a typical slab roof (thermal parameters summarized in Table 2) insulated with expanded polystyrene, and studied the effect of coatings with different solar absorptivity, given the climatic conditions of several cities.

Figures 8-10 show the results obtained for the cities of Hermosillo, Sonora, Monterrey, Nuevo Leon, and Mexico City, respectively. These cities fall within the BWh, BSh, and Cwb categories of the Köppen climate classification system, respectively corresponding to hot desert climate, hot semi-arid climate, and oceanic climate. The heat flux values required by NOM-020 for each city are achieved through thermal insulation, either by assuming high solar absorptivity as prescribed by NOM-020 (red lines) or by using constructions with variable absorptivity (blue lines).

Figures 8-10 show how building coatings with low absorptivity make it possible to achieve desired heat fluxes using much lower amounts of insulation. If the builder applies white waterproofing $(\alpha=0.42)$, as normally occurs in cities with warm climates, the insulation thickness needed would be $330 \mathrm{~mm}$ (1.13 in) and $101 \mathrm{~mm}$ (0.40 in) for Hermosillo and Monterrey, respectively, and Mexico City would require no insulation at all. The insulation thicknesses that NOM-020 recommends for these cities are: $517 \mathrm{~mm}$ (2.25 in), $457 \mathrm{~mm}$ (1.8 in), and $228 \mathrm{~mm}$ (0.90 in), respectively.

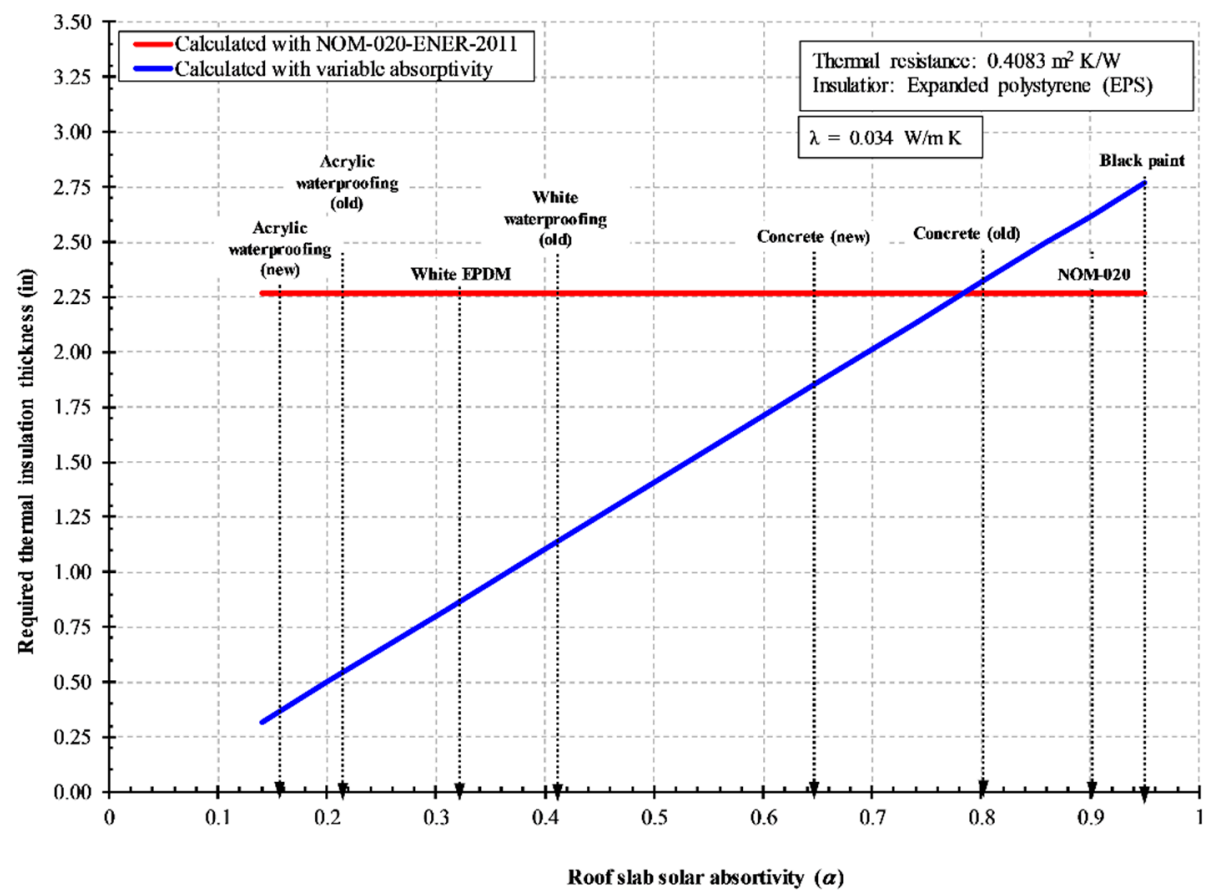

Figure 8. Roof insulation required to comply with NOM-020 in Hermosillo, Son.

Table 2. Thermal resistivity of a slab roof.

\begin{tabular}{|c|c|c|c|c|}
\hline Material & $\begin{array}{l}\text { Thermal Conductivity } \\
\text { (W/m K) }\end{array}$ & Thickness (m) & $\begin{array}{l}\text { Global Heat Transfer } \\
\text { Coefficient per Surface } \\
\text { Area }\left(\mathrm{W} / \mathrm{m}^{2} \mathrm{~K}\right)\end{array}$ & $\begin{array}{l}\text { Thermal Resistance per } \\
\text { Surface Area }\left(\mathrm{m}^{2} \mathrm{~K} / \mathrm{W}\right)\end{array}$ \\
\hline Exterior convective coefficient $\left(h_{e}\right)$ & & & 13.00 & 0.0769 \\
\hline Asphaltic waterproofing & 0.17 & 0.006 & 28.33 & 0.0352 \\
\hline Concrete & 1.65 & 0.04 & 41.25 & 0.0242 \\
\hline Dry sand for leveling & 2 & 0.06 & 33.33 & 0.0300 \\
\hline Reinforced concrete & 2 & 0.1 & 20.00 & 0.0500 \\
\hline Gypsum plastering & 0.372 & 0.015 & 24.80 & 0.0403 \\
\hline Interior convective coefficient $\left(h_{i}\right)$ & & & 6.60 & 0.1515 \\
\hline
\end{tabular}




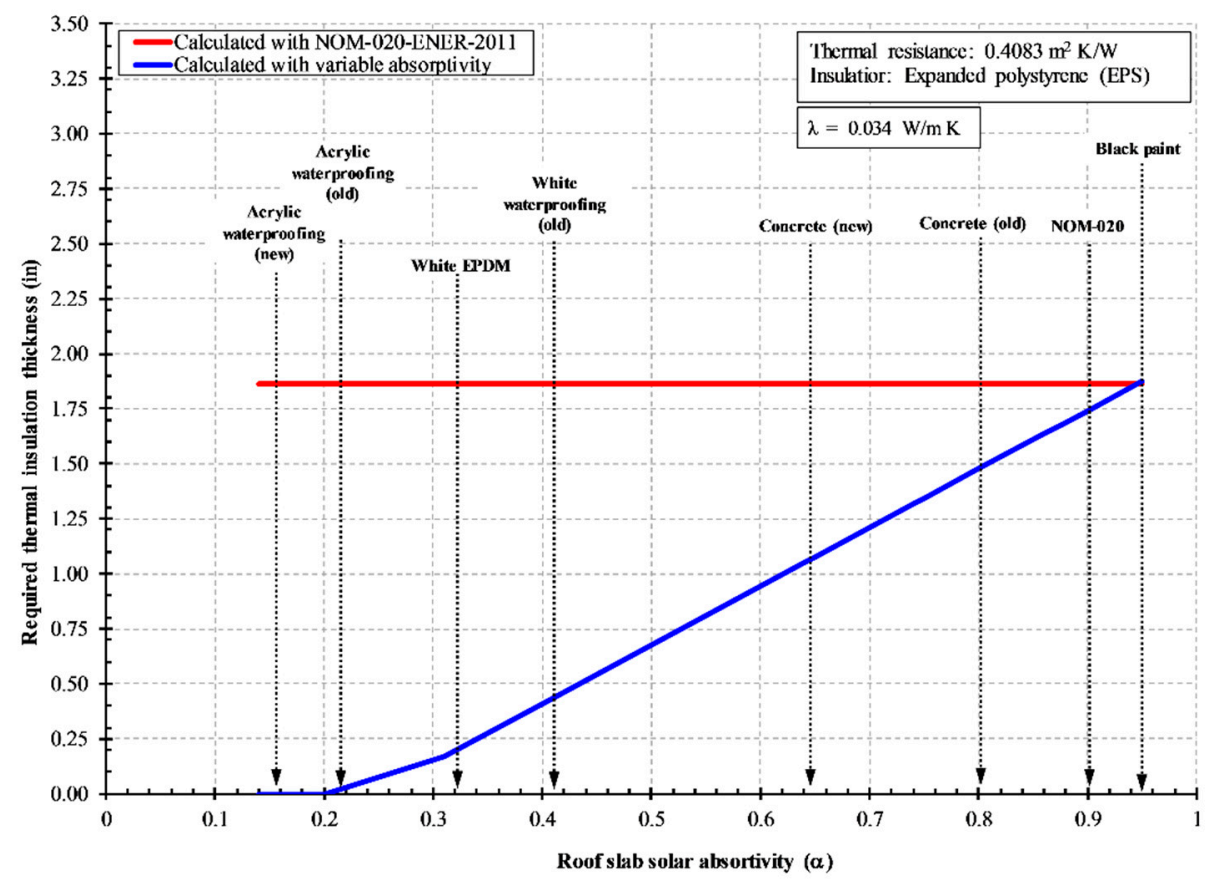

Figure 9. Roof insulation required to comply with NOM-020 in Monterrey, N.L.

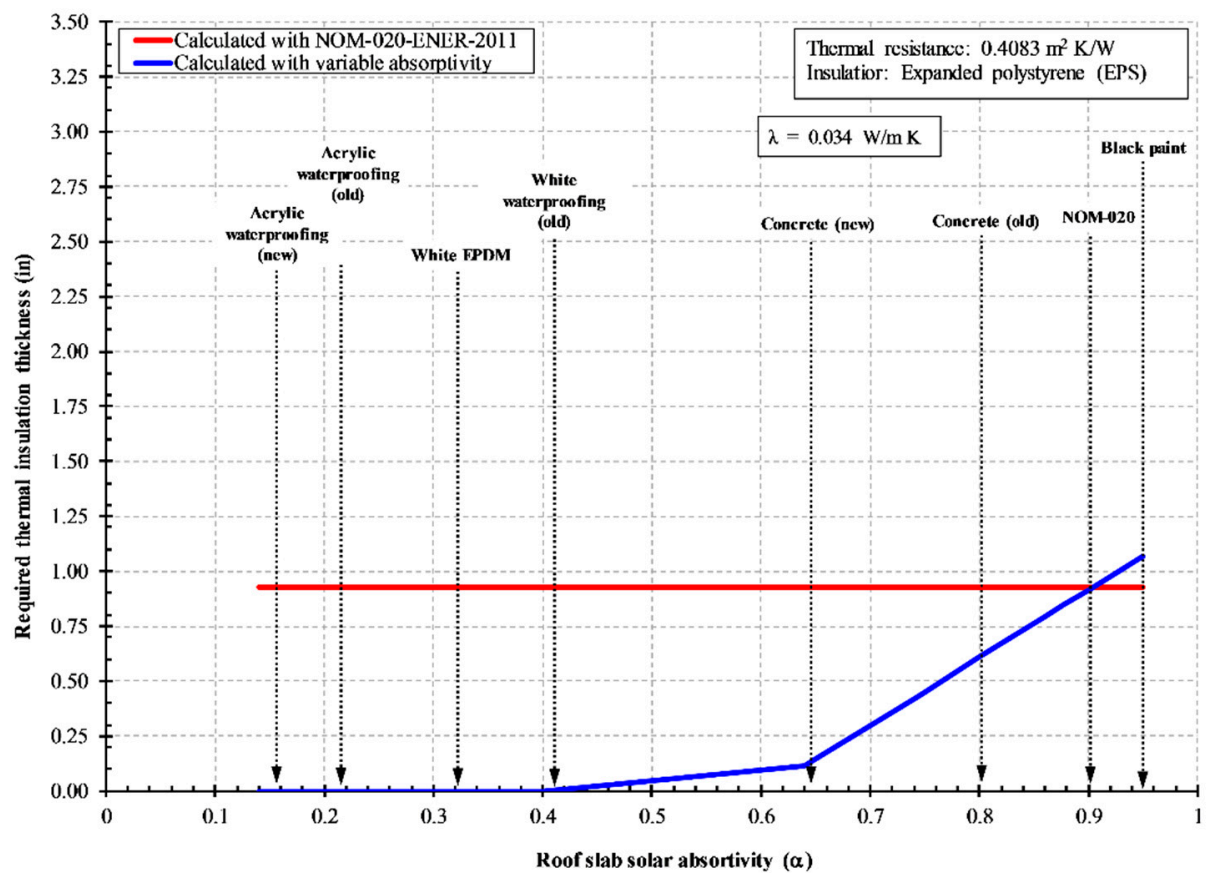

Figure 10. Roof insulation required to comply with NOM-020 in Mexico City.

Note that the insulation requirements above are only designed to prevent heat gains and reduce the use of air conditioning systems; they do not consider that cities with a temperate climate require a different insulation thickness due to heat losses during cold seasons.

\section{Conclusions}

The present study describes various technical weaknesses in the methodology of the Mexican federal building standard NOM-020-ENER-2011 (NOM-020). The federal standard implicitly assumes a very high solar radiation absorptivity for its reference buildings, though in fact, builders and homeowners have significant control over the materials used to coat their walls and roofs. For most 
climate zones throughout Mexico, the most cost-effective approaches to energy-efficient buildings rely on both thermal insulation and coatings with a low solar absorptivity. By always assuming a high absorptivity, NOM-020 effectively requires buildings to achieve their energy efficiency goals mostly through thick insulation.

Variable solar absorptivity could easily be incorporated into the methodology established by NOM-020. For this purpose, the AHSRAE methodology can be adopted for the calculation of equivalent temperatures. Furthermore, the use of highly reflective coatings can be both cost-effective during construction and also contribute to reducing HVAC operating costs due to the passive cooling effect. This study aims to highlight these issues in order to improve the applicability of Mexican federal building codes, and thus help them meet their original objective of reducing energy consumption in residential buildings.

Future work on this subject could include various comparisons of NOM-020, with and without the corrections mentioned in this work, against up-to-date standards for energy use in buildings. One useful benchmark would be ASHRAE's updated TETD methodology, especially using median monthly temperature values for each city (rather than arbitrarily assigning all cities one of four solar radiation levels, as prescribed in NOM-020). A second useful benchmark would be the ISO 52016-1:2017 [39] methodology. These comparisons could be the basis for an official recommendation to the Mexican Norms Committee, so that the next revision of the federal standard could better achieve its objective of reducing energy use in residential buildings.

Though the authors are not aware of other countries that use the simplifications encountered in NOM-020-ENER-2011, the methods presented in this work could also be used to evaluate and improve other building standards for energy efficiency.

Author Contributions: Conceptualization, I.R.M.-D.; Formal analysis, I.R.M.-D. and N.A.R.-M.; Funding acquisition, N.A.R.-M.; Investigation, C.K.R.-P.; Software, M.N.-T.; Visualization, M.N.-T.; Writing-original draft, I.R.M.-D. and C.K.R.-P.; Writing-review \& editing, N.A.R.-M., M.N.-T. and N.O.-A.

Funding: This research was funded by Mexican Center for Innovation in Solar Energy (CeMIE-Sol) grant number [P13] and the article processing charges were funded by Consejo Nacional de Ciencia y Tecnologia (CONACYT) project PDCPN-2015-1099.

Acknowledgments: The authors wish to thank Leonardo Martin-Alarcon and Daniel A. Martin-Alarcon for the proofreading and translation of this work.

Conflicts of Interest: The authors declare no conflict of interest.

\section{References}

1. Lucon, O.; Urge-Vorsatz, D.; Zain Ahmed, A.; Akbari, H.; Bertoldi, P.; Cabeza, L.F.; Eyre, N.; Gadgil, A.; Harvey, L.D.D.; Jiang, Y.; et al. Buildings. In Climate Change 2014: Mitigation of Climate Change. Contribution of Working Group III to the Fifth Assessment Report of the Intergovernmental Panel on Climate Change; Cambridge University Press: Cambridge, UK; New York, NY, USA, 2014; Volume 33, pp. 1-66. ISBN 0521880114.

2. Prindle, W. Energy Efficiency as a Low-Cost Resource for Achieving Carbon Emissions Reductions; U.S. Environmental Protection Agency: Washington, DC, USA, 2009; p. 86.

3. Passive House Institute. PHPP: The Energy Balance and Design Tool-For Efficient Buildings and Retrofits 2015. Available online: https:/ / passivehouse.com/04_phpp/04_phpp.htm (accessed on 18 October 2018).

4. USGBC. USGBC Leadership in Energy E Environmental Design (LEED); USGBC: Washington, DC, USA, 2016; p. 161.

5. ISO. ISO 13790:2008-Energy Performance of Buildings. Calculation of Energy Use for Space Heating and Cooling; ISO: Geneva, Switzerland, 2008.

6. Hitchin, R. Monthly utilisation factors for building energy calculations. Build. Serv. Eng. Res. Technol. 2017, 38, 318-326. [CrossRef]

7. Kwak, H.J.; Jo, J.H.; Suh, S.J. Evaluation of the reference numerical parameters of the monthly method in ISO 13790 considering s/v ratio. Sustainbility 2015, 7, 767-781. [CrossRef]

8. Spitler, J.D. Load Calculation Applications Manual; American Society of Heating, Refrigerating, and Air-Conditioning Engineers: Atlanta, GA, USA, 2009; p. 16. 
9. Enker, R.A.; Morrison, G.M. Analysis of the transition effects of building codes and regulations on the emergence of a low carbon residential building sector. Energy Build. 2017, 156, 40-50. [CrossRef]

10. Fossati, M.; Scalco, V.A.; Linczuk, V.C.C.; Lamberts, R. Building energy efficiency: An overview of the Brazilian residential labeling scheme. Renew. Sustain. Energy Rev. 2016, 65, 1216-1231. [CrossRef]

11. Friess, W.A.; Rakhshan, K. A review of passive envelope measures for improved building energy efficiency in the UAE. Renew. Sustain. Energy Rev. 2017, 72, 485-496. [CrossRef]

12. Evans, M.; Yu, S.; Staniszewski, A.; Jin, L.; Denysenko, A. The international implications of national and local coordination on building energy codes: Case studies in six cities. J. Clean. Prod. 2018, 191, 127-134. [CrossRef]

13. Sustainable Energy For All. Available online: https://www.seforall.org/ (accessed on 18 September 2018).

14. IPEEC. Delivering Energy Savings in Buildings-International Collaboration on Building Energy Code Implementation; IPEEC: Paris, France, 2015; p. 48.

15. D'Ambrosio Alfano, F.R.; Olesen, B.W.; Palella, B.I.; Riccio, G. Thermal comfort: Design and assessment for energy saving. Energy Build. 2014, 81, 326-336. [CrossRef]

16. International Energy Agency (IEA). Mexico Energy Outlook; IEA: Paris, France, 2016; p. 129.

17. SENER Balance Nacional de Energía. 2015 National Energy Balance-Mexico; Secretaria de Energia: Mexico City, Mexico, 2016; p. 136. Available online: https:/ /www.gob.mx/cms/uploads/attachment/file/288692/ Balance_Nacional_de_Energ_a_2016__2_pdf (accessed on 18 October 2018).

18. INEGI Censo de Población y Vivienda. Census of Population and Housing-Mexico; Instituto Nacional de Estadistica y Geografia: Mexico City, Mexico, 2010. Available online: http:/ /www.beta.inegi.org.mx/ proyectos/ccpv/2010/default.html (accessed on 18 October 2018).

19. CONUEE. Appliances and Spaces Consuming More Energy; Comision Nacional para el Uso Eficiente de la Energia: Mexico City, Mexico, 2009. Available online: http://www.conuee.gob.mx/wb/CONAE/espacio_ aparatos (accessed on 1 September 2015).

20. Fundación IDEA. Estrategia Nacional para la Vivienda Sustentable [National Strategy for Sustainable Housing-Mexico]; Fundacion IDEA, A.C.: Mexico City, Mexico, 2013; ISBN 9786079524937. Available online: https:/ / website-c230consultores.nyc3.digitaloceanspaces.com/IDEA/files/NationalStrategyforSustainableHousing_Eng_FINAL_ 1538591238.pdf (accessed on 18 October 2018).

21. INFONAVIT. INFONAVIT Plan Financiero 2016-2020; INFONAVIT Financial Plan; INFONAVIT: Mexico City, Mexico, 2016; p. 12. Available online: https:/ / portal.infonavit.org.mx/wps/wcm/ connect/b5470f62-a3344450-85cd-0dd9256064e3/Plan_Financiero_2015-2019.pdf?MOD=AJPERES (accessed on 18 October 2018).

22. Marincic, I.; Ochoa, J.M.; Barrera, I. La construcción actual de viviendas en Hermosillo y su adecuación al clima por medios pasivos [Current construction of houses in Hermosillo and its adaptation to climate by passive means]. In Proceedings of the Memorias de la XXXV Semana Nacional de Energía Solar, Chihuahua, Mexico, 5-7 October 2011; pp. 189-193.

23. Huelsz, G.; Ochoa, J.M.; López, P.E.; Gómez, A.; Figueroa, A. Uso de sistemas pasivos de climatización en cinco zonas de la república mexicana [Use of passive climate control systems in five zones of the Mexican Republic]. In Proceedings of the Memorias de la XXXV Semana Nacional de Energía Solar, Chihuahua, Mexico, 5-7 October 2011; pp. 177-182.

24. Elias-López, P.; Roux, R.; Espuma, A.; García, V. Caracterización y uso de sistemas pasivos de climatización en viviendas de la zona metropolitana de Tampico-Madero-Altamira, Tamaulipas [Characterization and use of passive systems in houses on the metropolitan area of Tampico-Madero-Altamira, Tamaulipas]. In Proceedings of the Memorias del XXXV Seemana Nacional de Energía Solar, Chihuahua, Mexico, 5-7 October 2011; pp. 166-170.

25. Barrios, G.; Huelz, G.; Rojas, J.; Ochoa, J.M.; Marincic, I. Parámetros para medir el desempeño térmico de muros/techos de la envolvente de una edificación que no usa aire acondicionado [Parameters to measure thermal performance of walls/ceilings of a building envelope without an air conditioning system]. In Proceedings of the Memorias XXXVI Semana Nacional de Energía Solar, Cuernavaca, Mexico, 1-5 October 2012; pp. 231-235.

26. Barrios, G.; Huelsz, G.; Rojas, J. Evaluación de sistemas constructivos de la envolvente en edificaciones con de aire acondicionado intermitente [Evaluation of constructive systems in buildings with intermittent air conditioning use]. In Proceedings of the Memorias del XXXV Congreso Nacional de Energía Solar, Chihuahua, Mexico, 5-7 October 2011; pp. 47-50. 
27. Lucero-Álvarez, J.; Martín-Domínguez, I.R. Effects of solar reflectance and infrared emissivity of rooftops on the thermal comfort of single-family homes in Mexico. Build. Simul. 2016. [CrossRef]

28. Diario Oficial de la Federación. NOM-020-ENER-2011. Eficiencia Energética en Edificaciones. Envolvente de Edificios para Uso Habitacional. [Energy Efficiency in Buildings: Residential Use]; Diario Oficial de la Federacion: Mexico City, Mexico, 2011; p. 49. Available online: http:/ /dof.gob.mx/nota_detalle.php?codigo=5203931\& fecha $=09 / 08 / 2011$ (accessed on 18 October 2018).

29. de Buen, R.O. Palabras Para el Arranque del $9^{\circ}$ Foro Permanente de Eficiencia Energética en la Edificación: Cumplimiento con la NOM-020-ENER-2011 [Inauguration Words of the 9th Permament Forum of Energy Efficiency in Buildings: Compliance with the NOM-020-ENER-2011]. Available online: http:/ / docplayer.es/37294175-Mexico-es-un-pais-con-un-territorio-donde-predomina-el-climacalido-lo-que-determina-que-45-de-los-usuarios-de-la-cfe-tenga-tarifas.html (accessed on 18 October 2018).

30. Diario Oficial de la Federación. RESOLUCIÓN de Modificación de la NOM-020-ENER-2011. [RESOLUTION of Modification of the NOM-020-ENER-2011]; Diario Oficial de la Federación: Mexico City, Mexico, 2016.

31. Diario Oficial de la Federación. Ley Federal Sobre Metrología y Normalización [Mexican Federal Law on Metrology and Standardization]; Diario Oficial de la Federación: Mexico City, Mexico, 1992; p. 48.

32. Diario Oficial de la Federación. NOM-008-SCFI-2002 Sistema General de Unidades de Medida [General System of Units of Measure]; Diario Oficial de la Federación: Mexico City, Mexico, 2002; p. 56.

33. International Organization for Standarization. ISO 31-4:1978 Quantities and Units of Heat. Available online: https: / www.iso.org/standard/3631.html (accessed on 31 October 2018).

34. Diario Oficial de la Federación. NOM-008-ENER-2001. Eficiencia Energética en Edificaciones. Envolvente de Edificios no Residenciales. [Energy Efficiency in Buildings: Non-Residential Use]; Diario Oficial de la Federacion: Mexico City, Mexico, 2001. Available online: http:/ /dof.gob.mx/nota_detalle.php?codigo=767644\&fecha= 25/04/2001 (accessed on 18 October 2018).

35. Martin-Domínguez, I.R.; Alarcón-Herrera, M.T. Evolución de las metodologías para el cálculo de cargas térmicas en edificaciones desarrolladas por la ASHRAE [Evolution of the ASHRAE calculation methodologies for thermal loads in buildings]. In Proceedings of the XXVIII Semana Nacional de Energia Solar, Oaxaca, Mexico, 4-8 October 2004.

36. ASHRAE. ASHRAE Fundamentals Handbook; ASHRAE: Atlanta, GA, USA, 2009.

37. Huang, J.; Warner, J.L.; Wiel, S.; Rivas, A.; de Buen, R.O. A commercial building energy standard for Mexico. In ACEEE Summer Study on Energy Efficiency in Buildings; ACEEE: Berkeley, CA, USA, 1998; pp. 153-164.

38. Servicio Meteorológico Nacional (Mexico). 1951-1980 Monthly Mean Temperature Data. Available online: http:/ / smn.cna.gob.mx/es/component/content/article?id=42 (accessed on 12 February 2011).

39. International Organization for Standarization. ISO 52016-1:2017 Energy Performance of Buildings-Energy Needs for Heating and Cooling, Internal Temperatures and Sensible and Latent Heat Loads-Part 1: Calculation Procedures. Available online: https://www.iso.org/standard/65696.html (accessed on 31 October 2018).

(C) 2018 by the authors. Licensee MDPI, Basel, Switzerland. This article is an open access article distributed under the terms and conditions of the Creative Commons Attribution (CC BY) license (http:/ / creativecommons.org/licenses/by/4.0/). 